This is a postprint (final draft post-refereeing) of an article published in

\title{
Plant and Soil
}

ISSN: 0032-079X (print version)

ISSN: 1573-5036 (electronic version)

It is acknowledged the permission

of the publisher SPRINGER

The definitive version is available in

http://link.springer.com/article/10.1007/s11104-012-1283-7

DOI: $10.1007 / \mathrm{s} 11104-012-1283-7$

Vázquez de Aldana B.R., Zabalgogeazcoa I., García Ciudad A., García Criado B.

An Epichloë emdophyte affects the competitive ability of Festuca rubra against other grassland species

Plant and Soil 362: 201-213 (2013)

For correspondence: beatriz.dealdana@irnasa.csic.es 
An Epichloë endophyte affects the competitive ability of Festuca rubra against other grassland species

Beatriz R. Vázquez-de-Aldana*, Iñigo Zabalgogeazcoa, Antonia García-Ciudad and Balbino García-Criado

Instituto de Recursos Naturales y Agrobiología de Salamanca, IRNASA-CSIC, Apartado 257, 37071 Salamanca, Spain

*Corresponding author: beatriz.dealdana@irnasa.csic.es,

Tel +34 923 219606; Fax +34 923219609

\begin{abstract}
Background and aims: Festuca rubra plants are asymptomatically infected by the systemic fungal endophyte Epichloë festucae and high infection rates have been found in natural grasslands. Our objective was to determine the effect of endophyte infection on the competitive ability of Festuca rubra in binary mixtures against other grassland species.

Methods: In two glasshouse experiments, endophyte-infected ( $\mathrm{E}+$ ) and non-infected (E-) plants of two half-sib lines (PEN, RAB) of Festuca rubra were grown in monocultures and in binary mixtures against five grassland species: Trifolium repens, Trifolium pratense, Trifolium subterraneum, Lotus corniculatus and Plantago lanceolata.

Results: Biomass production of F.rubra was affected by endophyte infection and plant line but not by competition with T.pratense. In the PEN line E+ plants produced less root biomass than $\mathrm{E}-$; and in the RAB line E+ plants produced less shoot biomass than E-. In spite of these differences shoot and root biomass production of Trifolium pratense were more inhibited when growing with endophyte-infected plants of Festuca rubra than with E- plants, regardless of the plant line. In both F.rubra lines, the endophyte increased the phosphorus concentration in shoots. Regardless of F.rubra plant line, root biomass of the five target species was more inhibited when growing with endophyte-infected than with endophyte-free plants.

Conclusions: Irrespective of F.rubra line, endophyte-infected plants had a better competitive ability than non-infected plants, as indicated by the lower relative yield of companion plants when growing in mixture with $\mathrm{E}+$ plants. We suggest an allelopathic effect of $\mathrm{E}+$ red fescue on other grassland species.
\end{abstract}


Keywords: endophyte-plant interactions; red fescue; Epichloë festucae; root biomass; phosphate uptake; allelopathy

\section{Introduction}

Endophytes are a group of fungi characterized by being able to infect their plant hosts without causing obvious symptoms in them. This group of fungi is highly diverse and there are no plant species free of them (Rodriguez et al. 2009).

Clavicipitaceous endophytes of the Neotyphodium and Epichloë genera systemically infect the aerial tissues of several economically important turf and forage grasses. Transmission of these endophytes is primarily vertical, in infected plants the fungi are efficiently transmitted to their offspring via seed infections. The endophyte-grass interaction has been described as a mutualism and the benefits conferred by fungi appear to depend on the host genotype, fungal genotype and ecological context (Clay 1988; Saikkonen et al. 2004). On the other hand, the host plant provides food, shelter and a mode of reproduction for the fungus. The main endophyte-induced benefit is due to the production of a range of alkaloids in the host plants, some of which have antiherbivore activity (Siegel and Bush 1996; Belesky and Bacon 2009) increasing resistance to mammals, insects and nematodes (Clay and Schardl 2002). For some authors this is the basis of the grass-endophyte mutualism (Bush et al. 1997; Leuchtmann et al. 2000). Furthermore, endophytes improve host tolerance to abiotic stresses such as drought and metal toxicity (Malinowski and Belesky 2000).

Endophytes may have strong influences on plant community composition by altering the performance of host grasses relative to other species present in the community. Thus, the frequency of endophyte-infected individuals often increases in grass populations over time (Shelby and Dalrymple 1993; Clay and Holah 1999; Clay et al. 2005), suggesting that endophytes confer a competitive advantage to their hosts, even though the host may incur a cost.

The effects of the endophyte on host growth under intra- or inter-specific competition have been found to be variable. In binary mixtures of infected and non-infected plants, the greater competitive ability of plants harbouring the endophyte has been linked to: (i) a greater shoot and/or root growth in Festuca pratensis (meadow fescue) (Malinowski et al. 1997), Lolium arundinaceum (tall fescue) (Hill et al. 1991; Marks et al. 1991), and Bromus benekenii (Brem and Leuchtmann 2002); (ii) to increased vigour of endophyte infected plants attributed to pest and herbivore resistance, probably due to endophyte alkaloids (Clay et al. 1993; Schardl and Phillips 1997), although Hill et al. (1991) reported that high ergopeptine alkaloid-producing 
infected tall fescue plants have no more competing capability than low ergopeptine alkaloid plants, and (iii) in other cases of interspecific competition, the greater competitiveness of tall fescue infected plants with respect to legumes have been explained as an allelopathic effect (Malinowski et al. 1999). On the other hand, some works have recorded neutral or negative effects of the symbiosis when infected plants grow in competition with other species (Hoveland et al. 1997; Richmond et al. 2003; Renne et al. 2004).

In this study we focused on Festuca rubra L. (red fescue), a perennial grass tolerant of a wide range of ecological conditions and one of the most important turfgrass species in temperate regions. Festuca rubra is a common species of savannah-like semiarid grasslands of western Spain, known as 'dehesas'. Dehesa grasslands are characterized by a high floristic diversity where grasses, legumes and forbs are well represented and compete for resources (Vázquezde-Aldana et al. 2008). The associations between Epichloë festucae Leuchtmann, Schardl \& Siegel and Festuca rubra in these ecosystems seem to be old. Dehesa grasslands are part of a centre of diversity of red fescue (Saint Yves 1930), and in them about $70 \%$ of the F. rubra plants are infected by the fungal endophyte E. festucae (Zabalgogeazcoa et al. 1999). Wild populations of $F$. rubra in dehesas are an important reservoir of genetically diverse $E$. festucae strains (Arroyo Garcia et al. 2002) whose diversity includes high variability in the plant contents of the fungal alkaloids ergovaline and peramine (Vázquez-de-Aldana et al. 2010).

The association between E. festucae and F. rubra is considered a mutualism. The incidence of infected plants can vary due to grazing level and altitude (Bazely et al. 2007). Increased herbivore and disease resistance (Bazely et al. 1997; Wilkinson et al. 2000; Ahlholm et al. 2002), aluminium tolerance (Zaurov et al. 2001) and seed survival (Gundel et al. 2011) has been linked to the association between E. festucae and F. rubra. On the other hand, some effects on host seedlings have been variable (Wäli et al. 2009), and no differences in aboveground plant biomass production between infected and non-infected plants were found in a field experiment (Zabalgogeazcoa et al. 2006).

Our objective was to determine the effect of endophyte infection on the competitive ability of Festuca rubra in binary mixtures with other grassland species under controlled conditions. Based on the high endophyte infection rates occurring in semiarid grassland ecosystems, our hypothesis was that infected plants would have a better competitive ability than non-infected plants. Specific objectives were: i) to determine the effect of the endophyte symbiosis on above and below ground growth parameters of $F$. rubra in response to competition with other herbaceous species (Trifolium pratense L.), and ii) to determine the effect of the endophytic symbiosis on the growth of five competing herbaceous species frequent in grasslands (Trifolium repens L., Trifolium pratense, Trifolium subterraneum L., Lotus corniculatus L. and 
Plantago lanceolata L.), to find out if there is a differential response of target species in competition with symbiotic F. rubra.

\section{Materials and Methods}

Plant Material

Seeds of two half-sib lines of Festuca rubra were used in this study. Each half-sib line consisted of plants infected $(\mathrm{E}+)$ and not infected (E-) by the same genotype of Epichloë festucae. To develop the half-sib lines, F. rubra plants infected with E. festucae were collected at Peña (PEN) and at Raboso (RAB), two dehesa grasslands located $70 \mathrm{~km}$ apart in the province of Salamanca (western Spain). Dehesa ecosystems feature low-density Quercus ilex L. subsp. ballota (Desf.) Samp. with natural grassland of a complex floristic composition. This land is mainly used for the free-range grazing of beef cattle and fighting bulls. The climate is supraMediterranean, with cold winters and dry, warm summers.

Infection by E. festucae was verified by microscopic analysis of stem pith scrapings, as well as by isolation of the fungus from plant stems and leaf sheaths in Petri dishes containing potato dextrose agar (PDA) (Bacon and White 1994). One infected plant from each location was transplanted to a pot containing a mixture of peat moss and perlite, and was allowed to undergo vegetative growth for one month. Then, each plant was divided into several ramets, which were transplanted into $75-\mathrm{mL}$ pots and maintained in a growth chamber with a $16 \mathrm{~h}$ light photoperiod at $25^{\circ} \mathrm{C}$. The endophyte was eliminated from half of the ramets of each plant using a treatment with three doses of $400 \mu \mathrm{g}$ of propiconazole (TILT, $400 \mathrm{mg}$ a.i. $\mathrm{L}^{-1}$, CIBA, Basel, Switzerland), a systemic fungicide. The first and third doses were applied to the soil, and the second was a foliar application. Fungicide treatments were spaced by 10 days between applications. Treated and untreated plants were then transplanted to the field in a research farm near Salamanca. From these plants, infected $(E+)$ and uninfected $(E-)$ seeds were obtained. Thus, non-infected plants were the seed progeny obtained from infected plants treated with a fungicide. Infected and non-infected plants grown from these seeds should have the same chance of being infected by horizontally transmitted endophytes, and the only difference between them should be the presence of the endophyte Epichloë festucae. Unlike Epichloë and Neotyphodium sp. which are vertically transmitted by seeds, most known endophytes are not capable of seed transmission, and plants acquire these other horizontally transmitted endophytes after germination (Sanchez Marquez et al. 2012). 
The seeds of the target species Trifolium pratense (red clover), Trifolium repens (white clover), Trifolium subterraneum (subterraneam clover) Lotus corniculatus (bird's foot trefoil), and Plantago lanceolata (ribwort plantain) were obtained from commercial suppliers. All species are perennials except the annual subterranean clover.

Experiment I: Growth of Festuca rubra and Trifolium pratense in mixtures

This experiment was designed to analyse above and below ground growth and nutrient content of $F$. rubra and T. pratense, in a competition experiment.

Seedlings of Festuca rubra (E+, E-) from lines PEN and RAB were grown in a potting soil containing peat moss and perlite $(2: 1 \mathrm{v} / \mathrm{v})$ in a glasshouse. The mixture had $\mathrm{pH}\left(\mathrm{H}_{2} \mathrm{O}\right)=5.3$, and its organic matter and nitrogen contents were $70.2 \%$ and $0.76 \%$ respectively. The available phosphorus content of the mixture was very high $\left(256 \mathrm{mg} \mathrm{kg}^{-1}\right)$. After four months, the presence of Epichloë festucae was verified by isolation of the fungus from leaf sheaths on PDA, as previously indicated. Two months later, plants of similar size with two tillers were selected. Each plant was weighted after trimming to $5-6 \mathrm{~cm}$ height and $5 \mathrm{~cm}$ of roots. Plants with similar fresh weight were selected and individually transplanted into pots (15 cm diameter) containing the potting mix and placed in a glasshouse for eight weeks.

The experiment consisted of monocultures of infected (PEN E+, RAB E+) and non-infected (PEN E-, RAB E-) F. rubra, monocultures of $T$. pratense (Tp), and mixtures of $F$. rubra and $T$. pratense (PEN E+/Tp and PEN E-/Tp, RAB E+/Tp and RAB E-/Tp), with five replicates. Ten seeds of $T$. pratense were sown in each corresponding pot (in mixture with $F$. rubra or in monoculture). The experiment contained a total of 45 pots placed at random in a glasshouse at temperature $22 / 15{ }^{\circ} \mathrm{C}$ day/night and ambient light conditions of late spring. Red clover emergence was observed daily and, ten days after sowing, each pot was thinned to five similar seedlings. Plants were watered regularly and no fertilizer was added. Four weeks after sowing the red clover, all plants were harvested. Shoot and root dry weight was determined for each species. The number of tillers was counted in F. rubra plants.

In red fescue samples, total nitrogen was measured by colorimetric analysis with a segmented flow system (AutoAnalyzer 3 BRAN+LUEBBE). Red fescue and red clover samples were calcined $\left(450{ }^{\circ} \mathrm{C}\right.$ ) and ashes dissolved in $\mathrm{HCl}: \mathrm{HNO}_{3}: \mathrm{H}_{2} \mathrm{O}(1: 1: 8)$; then, phosphorus concentration was determined spectrophotometrically as molybdovanadophosphoric acid.

Data relative to $F$. rubra was analysed by means of a three-way ANOVA considering as factors line (PEN, RAB), endophyte infection ( $E+, E-)$ and competition (monoculture vs. mixture). Data relative to $T$. pratense was analysed by means of a two-way ANOVA considering as factors line 
(PEN, RAB) and competition with F. rubra (mono, E+, E-). All data analyses were performed with Statistica for Windows 5.0 (StatSoft Inc., Tulsa, OK, USA).

The competitive ability of species $x$ relative to species $y$ grown in a binary mixture can be described by the aggressivity index (AGR), as definded by McGilchrist and Trenbath (1971):

$$
A G R x y=R Y x-R Y y=(D M x y / D M x x)-(D M y x / D M y y)
$$

Where RY is the relative yield of species $x$ or $y$, which is the dry matter yield of a species grown in mixture (DM $x y$ or $D M y x$ ) relative to the dry matter in the respective monoculture (DM $x x$ or DM yy). Species $x$ and $y$ have the same competitive ability if AGRxy value is zero. An AGRxy index greater than zero indicates higher competitive ability of species $x$ than that of species $y$. A negative AGRxy value indicates the opposite.

Experiment II: Effect of $F$. rubra on emergence and growth of five target species

A second experiment was carried out to evaluate the effect of the endophyte status of two lines of $F$. rubra on the emergence and growth of five grassland species (T. pratense, $T$. repens, T. subterraneum, L. corniculatus and P. lanceolata).

Seedlings of Festuca rubra (PEN E+, PEN E-, RAB E+ and RAB E-) were grown in a potting soil containing peat moss and perlite in a glasshouse for six months as previously indicated for experiment I. Then, plants of similar size aboveground were transplanted to pots $(15 \mathrm{~cm}$ diameter) and placed in a growth chamber with a photoperiod of $16 \mathrm{~h}$ light at $25{ }^{\circ} \mathrm{C}$ and $8 \mathrm{~h}$ dark at $20{ }^{\circ} \mathrm{C}$ during two acclimatization weeks. The experiment consisted of binary mixtures of $F$. rubra (PEN E+, PEN E-, RAB E+ and RAB E-) and one companion species (T. pratense, $T$. repens, T. subterraneum, L. corniculatus, or P. lanceolata) and monocultures of each companion species. For each companion species, besides its monoculture, a factorial combination with five replications of line (PEN and RAB) and infection status (E+, E-) was considered. The experiment contained a total of 125 pots ( 25 for each target species). Ten seeds of each companion species were sown in each pot in binary mixtures with $F$. rubra and in monoculture.

Seedling emergence was observed daily for two weeks until no further seedlings emerged. Emergence applies to those seedlings visible above soil surface. After 21 days, plants of Trifolium repens, Trifolium pratense, Trifolium subterraneum, Lotus corniculatus, and Plantago lanceolata were removed from each pot and their roots cleaned gently by washing away clinging soil with water. Root and shoot lengths were measured from scanned images of the 
plants obtained in a desk scanner using the Soft Imaging System software (Olympus). Root and shoot biomass were obtained from samples dried at $60^{\circ} \mathrm{C}$ during 48 hours.

Dry matter production of target species grown in mixture with $F$. rubra were compared to those in the respective monoculture and defined as relative yield ( $R Y)$ as $R Y=D M_{\text {mixture }} / D M_{\text {mono. }}$. Data was analysed by means of a two-way ANOVA considering as factors line (PEN, RAB) and endophyte infection ( $\mathrm{E}+\mathrm{E}-\mathrm{E}$ ). All data analyses were performed with Statistica for Windows 5.0 (StatSoft Inc., Tulsa, OK, USA).

\section{Results}

Experiment I: Growth of Festuca rubra and Trifolium pratense in mixtures

\section{Growth and nutrient content of Festuca rubra}

Growth of $F$. rubra, in terms of shoot and root dry matter was not significantly affected by competition with $T$. pratense (Table 1).

The endophyte infection status affected shoot biomass, root biomass and number of tillers depending on the plant line (Table 1). Non-infected plants had significantly greater shoot biomass and number of tillers than infected plants in the RAB line, but there were no differences associated to the infection in the PEN line (Fig. 1). Conversely, in PEN line noninfected plants had greater root biomass than $\mathrm{E}+$, and in the RAB line differences between $\mathrm{E}+$ and E- were not statistically significant (Fig. 1). In PEN line the root:shoot ratio was greater in E- than in E+ plants, and the opposite occurred in the RAB line. Regardless of endophyte status, RAB plants had significantly greater shoot biomass, root biomass and number of tillers than PEN plants.

Nitrogen concentration in shoots of $F$. rubra was significantly affected by the interaction line $x$ infection (three way ANOVA: $F=7.63, P<0.01$ ): In RAB line, $E+$ plants had significantly greater $\mathrm{N}$ concentration than $\mathrm{E}-$, however in PEN line differences between $\mathrm{E}+$ and $\mathrm{E}-$ were not statistically significant (Fig. 2). Nitrogen concentration in roots of $F$. rubra was not significantly $(P>0.1)$ affected by any factor.

Endophyte infection increased phosphorus concentration of $F$. rubra in shoots (three way ANOVA: $F=223, P<0.001$ ) and in roots (three way ANOVA: $F=18.4, P<0.001$ ) (Fig. 2 ). The $P$ concentration also depended on line: RAB had greater content in shoots and roots than the PEN line (three way ANOVA: $F=8.07, P<0.01$ in shoots; $F=337, P<0.001$ in roots). The ANOVA did not show any significant interaction between factors. 


\section{Growth and phosphorus content of Trifolium pratense}

Growth of $T$. pratense was reduced when growing in mixture with $F$. rubra and this reduction was significantly influenced by the infection status of the companion grass (two way ANOVA: $F$ $=6.59, P<0.05$ in shoots, $F=5.01, P<0.05$ in roots). Red clover produced more shoot and root dry matter when grown in mixture with E- than with E+ plants (Fig. 3). Growth of T. pratense was not significantly $(P>0.05)$ influenced by line of $F$. rubra.

Shoot samples of red clover were analysed for phosphorus content, but roots could not be analysed due to the insufficient amount of sample. The phosphorus concentration in red clover was not significantly $(P>0.05)$ affected by competition with $F$. rubra, and no differences between clover growing with E+ and E- were found (Fig. 3).

\section{Competitive ability of Festuca rubra against Trifolium pratense}

The aggressivity index (AGR) was used to measure the competitive ability of $F$. rubra relative to T. pratense. Considering total dry matter production (both shoot and roots) of each plant species, the indices of $F$. rubra against red clover for each endophyte status and fescue line were: $\mathrm{E}-\mathrm{PEN}=0.5603 ; \mathrm{E}+\mathrm{PEN}=0.7998 ; \mathrm{E}-\mathrm{RAB}=0.1719 ; \mathrm{E}+\mathrm{RAB}=0.9140$. All indices were greater than zero indicating greater competitive ability of $F$. rubra than red clover. Regardless of plant line, endophyte-infected plants had higher AGR than non-infected plants.

Experiment II. Effect of $F$. rubra on emergence and growth of $T$. pratense, $T$. repens, $T$. subterraneum, L. corniculatus and P. Ianceolata

\section{Emergence percentage}

There were no significant differences for any companion species $(P>0.05)$ in the percentage of emergence between seeds sown in pots with $\mathrm{E}+$ or E- plants. At the end of the experiment, the percentages of emergence averaged $70.0 \pm 4.8 \%$ in $T$. pratense; $96.5 \pm 1.8 \%$ in $T$. repens; $51.5 \pm 4.8 \%$ in T. subterraneum, $63.5 \pm 4.8 \%$ in L. corniculatus, and $92.5 \pm 2.6 \%$ in P. lanceolata.

\section{Above and below ground biomass}

Shoot and root dry matter weight of target species were significantly influenced by the endophyte status of the companion F. rubra but the effect of plant line was significant only for shoot of $T$. repens (Table 2). When growing in mixture with $\mathrm{E}+$ plants, the root biomass of the five target species was significantly smaller than when growing with E- plants (Fig. 4). Shoot biomass of $T$. pratense, $T$. repens and $P$. lanceolata was less when growing with $\mathrm{E}+$ plants than 
when growing with E- plants, however in T. subterraneum and L. corniculatus shoot biomass was not significantly affected by endophyte infection (Table 2, Fig. 4).

The target species more affected by the by the presence of $F$. rubra were $T$. pratense and $T$. repens.

\section{Plant length}

Roots of $T$. pratense, $T$. repens, $T$. subterraneum and $P$. lanceolata were significantly shorter when grown in mixture with $\mathrm{E}+$ plants than with $\mathrm{E}-$ plants (Table 2, Fig. 4). The infection of $F$. rubra plants also had a significant negative effect on shoot length of $T$. repens and $L$. corniculatus (Fig. 4). In T. repens the effect of endophyte infection was dependent on line (Table 2), the differences between E+ and E- were statistically significant for PEN line but not for the RAB line.

\section{Discussion}

The extent to which a plant species adapts and dominates in the environment depends on a suite of traits associated with the rate of depletion of mineral nutrients and water in soils, release of phytotoxic compounds, seed production and rate of germination and growth (Grime 1979).

Growth of Festuca rubra did not vary in response to competition with $T$. pratense. This was expected since there were large differences in plant biomass between $F$. rubra and $T$. pratense (Figs. 1 and 3), associated to the different age of plants. Red fescue is a slow-growing perennial species and after four months of growth in the above mentioned conditions, plant biomass was low. That is why the experiment was designed to test the early-growth response of red clover using older red fescue plants. In nature, red fescue can propagate vegetatively by expansive growth of individual genets (Harberd 1961). Therefore, circumstances where $F$. rubra plants compete with other plant species of younger age are likely to occur in botanically complex settings like dehesa grasslands.

In the PEN line the root:shoot ratio was greater in E- than in E+ plants, and the opposite occurred in the RAB line. In spite of the differences in growth characteristics of $F$. rubra associated to line and endophyte factors, in both lines the endophyte had an inhibitory effect on the growth of the companion species ( $T$. pratense). The less shoot and root biomass production of $T$. pratense in mixture with endophyte-infected plants, as compared to the growth with E- (Fig. 3), would suggest a greater biomass of E+ as compared to E- plants. However, in PEN line root biomass was greater in E- than in E+ plants, and no significant effect 
of endophyte on shoot biomass or tiller number was found; and in the RAB line, E- plants had greater shoot biomass and tiller number than $\mathrm{E}+$ and no differences in root biomass between $\mathrm{E}+$ and $\mathrm{E}-$ were detected (Fig. 1). These results suggest that in both lines the endophytemediated inhibitory effect on $T$. pratense growth is not due to increased biomass production or tiller number of $F$. rubra. In terms of the aggressivity index of $F$. rubra relative to $T$. pratense, the values of $E+$ plants $(P E N=0.799 ; R A B=0.914)$ were greater than those of $E$ - plants $(P E N=0.560 ; R A B=0.172$ ) indicating higher competitive ability of $E+$ than $E-$ plants. Moreover, in both plant lines, with different biomass allocation patterns, we found greater phosphorus concentration in $\mathrm{E}+$ than in $\mathrm{E}$ - plants. However, the phosphorus content of $T$. pratense did not vary between plants in monoculture or growing with $F$. rubra $(E+$ or $E-)$, suggesting that the inhibitory effect on $T$. pratense biomass production is not due to a depletion of nutrients due to competition with F. rubra. These results suggest that the reduction in growth of $T$. pratense when growing with endophyte-infected $F$. rubra could be due to a release of phytotoxic compounds, that is an allelopathic effect.

The greater competitive ability of endophyte-infected tall fescue plants growing in intraspecific competition with E- plants, under field conditions, has been related to a greater biomass production of E+ plants (Hill et al. 1991), but this was not the result of the present work. Our results resemble those of Malinowski et al. (1999) who found that root growth of red clover was significantly depressed in competition with $\mathrm{E}+$ tall fescue plants respectively to $\mathrm{E}$ - plants, and the enhanced competitive ability of E+ tall fescue plants was related to an allelopathic effect, perhaps the involvement of pyrrolizidine alkaloids produced by the infected plants. In a recent study with assays in Petri dishes we reported that, as compared to E- plants, root extracts of $E+F$. rubra plants had a greater concentration of phenolic compounds, and caused a greater growth inhibition on several legume species, suggesting that the endophyte may increase the allelopathic potential of F. rubra (Vázquez-de-Aldana et al. 2011). Phenolic compounds constitute a large group of allelochemicals, consisting of structures with different degrees of chemical complexity. Epichloë and Neotyphodium endophytes enhanced the concentration of phenolic compounds in roots of Italian ryegrass (Lolium multiflorum) (Ponce et al. 2009), tall fescue (Malinowski et al. 1998a), F. rubra (Vázquez-de-Aldana et al. 2011) and Lolium perenne (Torres et al. 2012).

Our study showed that in binary mixtures with F. rubra, the growth of all grassland species used in the experiment, $T$. pratense, $T$. repens, $T$. subterraneum, L. corniculatus and $P$. lanceolata, was negatively affected by the endophyte status of red fescue. Root biomass and root length of the species were more affected than shoot biomass. Furthermore, all target species had lower root biomass when growing with $\mathrm{E}+$ plants, but only three species had lower 
shoot biomass. Since phytotoxic compounds are mainly released through the roots of the allelopathic plant species, it seems feasible that the parameter most affected is the root growth of the target species. The inhibitory effect on roots seems to be the most sensitive indicator of growth inhibition in allelopathic experiments (Bertin et al. 2003; San Emeterio, et al. 2004; Vázquez-de-Aldana et al. 2011).

Besides allelopathic interactions, many chemicals released from the roots of plant species function to make nutrients available often through chelation and pH modifications (Inderjit et al. 2011). Phenolic compounds and other root exudates can increase $P$ availability in the soil by binding soluble Al, Fe, and Mn (Marschner 1995). We found that, in both lines, in spite of differences in biomass allocation, the endophyte increased $\mathrm{P}$ concentration in shoots and roots of $F$. rubra plants. This increased $\mathrm{P}$ concentration was not due to the presence of mycorrhizal fungi in roots of $F$. rubra plants (data not shown). Similarly, in a field experiment with five lines of $F$. rubra, infected plants had greater $\mathrm{P}$ concentration in shoots than $\mathrm{E}$ - plants (Zabalgogeazcoa et al. 2006). These results are in accordance with those of Malinowski et al. (1998b) who found a greater P concentration in endophyte-infected tall fescue at low soil P level, and reported that a possible mechanism for increased $\mathrm{P}$ uptake in endophyte-infected plants was an increased activity of root exudates, with phenolic compounds occurring in greater amounts in roots and shoots of E+ plants (Malinowski et al. 1998a).

Several studies have indicated that endophyte infected plants experience a considerable competitive advantage over non-infected plants. However, in heterogeneous environments, circumstances may arise in which endophyte infection is deleterious to the plant and competition with the fungus for nutrients or photosynthate may reduce plant growth thereby reversing the advantage of endophyte infection (Cheplick et al. 1989; Ahlholm et al. 2002; Hesse et al. 2004). In other circumstances, the plant endophyte associations appear neutral, and in several studies no differences in biomass production between $\mathrm{E}+$ and $\mathrm{E}$ - plants were found (Hoveland et al. 1997; Malinowski et al. 1999; Vázquez-de-Aldana et al. 1999). Considering only the data of biomass production, our study also would indicate that the endophyte may have a negative effect on plant growth (Fig. 1). However, our results showed a deleterious effect of endophyte on the growth of several companion species, and a positive effect on $\mathrm{P}$ concentration in the plant, which can provide benefits in a situation where interspecific competition occurs and nutrient resources are limited. The inhibitory effect of the endophyte on growth of companion species was recorded in the five target species, which are frequent in grasslands, regardless the host plant line. It is important to point out that the inhibitory effect was not dependent on the Festuca rubra host plant line, given that endophyte effects on host plant performance are often determined by host plant genotype (Malinowski et 
al. 1999; Hesse et al. 2004; Wäli et al. 2009; Gundel et al. 2011). These results suggest that the inhibition was not a selective effect of a particular plant-fungus combination recorded on a single competing species, and therefore may have a significant impact at the population level. In a previous three-year field study with five F. rubra lines, no differences in aboveground biomass production, in vegetative or reproductive stages, were observed among $\mathrm{E}+$ and $\mathrm{E}$ plants (Zabalgogeazcoa et al. 2006). The F. rubra plants used in that previous work and in the present study were obtained from natural populations having a mean infection rate of $70 \%$ (Zabalgogeazcoa et al. 1999). The fact that we have found an inhibitory effect of E+ plants on companion species might help to explain the forces maintaining the high prevalence of Epichloë festucae in F. rubra populations. Festuca rubra is a common species in the botanically complex grasslands of western Spain, where interspecific competition among pasture species is evident. Festuca rubra plants can vegetatively expand forming large and old genets, and also can produce seeds (Harberd 1961). Plants infected by Epichloë contain fungal hyphae in their vegetative aerial organs, and in the seeds they produce, therefore, an allelopathic competitive advantage for vegetative growth would increase the fitness of plant and fungus in a situation of competition with other species.

We have shown that there is a relevant effect of the endophyte infection in F.rubra when grown together with other grassland species such as T. repens, $T$. pratense, $T$. subterraneum, $L$. corniculatus and $P$. lanceolata. Festuca rubra infected plants showed a better competitive ability than non-infected plants as indicated by the lower relative yield of companion plant species when growing in mixture with E+ plants. This effect was independent of the host plant line. Our results suggest that a chemically mediated plant-plant interference, or allelopathy, could be the mechanism by which endophyte-infected $F$. rubra may gain an advantage in competition with T. pratense and other grassland species (over non-infected).

\section{Acknowledgements}

This work was funded by project AGL2008-01159AGR from the Spanish Ministry of Science and Innovation and FEDER. We thank to Dr Esther Perez Corona for her valuable suggestions which improved the manuscript, to Amador Alvarez for the tedious cleaning of roots and to Pilar Casado and Maria Romo for technical help.

\section{References}


Ahlholm JU, Helander M, Lehtimaki S, Wali P, Saikkonen K (2002) Vertically transmitted fungal endophytes: different responses of host-parasite systems to environmental conditions. Oikos 99:173-183

Arroyo Garcia R, Martinez Zapater JM, Garcia Criado B, Zabalgogeazcoa I (2002) Genetic structure of natural populations of the grass endophyte Epichloë festucae in semiarid grasslands. Mol Ecol 11:355-364

Bacon CW, White JF (1994) Stains, media and procedures for analyzing endophytes. In: Bacon CW, White JF (eds) Biotechnology of Endophytic Fungi of Grasses. CRC Press, Boca Raton. pp. 47-56

Bazely DR, Vicari M, Emmerich S, Filip L, Lin D, Inman A (1997) Interactions between herbivores and endophyte-infected Festuca rubra from the Scottish islands of St. Kilda, Benbecula and Rum. J Appl Ecol 34:847-860

Bazely DR, Ball JP, Vicari M, Tanentzap AJ, Berenger M, Rakocevic T, Koh S (2007) Broad-scale geographic patterns in the distribution of vertically-transmitted, asexual endophytes in four naturally-occurring grasses in Sweden. Ecography 30:367-374

Belesky DP, Bacon CW (2009) Tall fescue and associated mutualistic toxic fungal endophytes in agroecosystems. Toxin Reviews 28:102-117

Bertin C, Paul RN, Duke SO, Weston LA (2003) Laboratory assessment of the allelopathic effects of fine leaf fescues. J Chem Ecol 29:1919-1937

Brem D, Leuchtmann A (2002) Intraspecific competition of endophyte infected vs uninfected plants of two woodland grass species. Oikos 96:281-290

Bush LP, Wilkinson HH, Schardl CL (1997) Bioprotective alkaloids of grass-fungal endophyte symbioses. Plant Physiol 114:1-7

Clay K (1988) Fungal endophytes of grasses: a defensive mutualism between plants and fungi. Ecology 69:10-16

Clay K, Marks S, Cheplick GP (1993) Effects of insect herbivory and fungal endophyte infection on competitive interactions among grasses. Ecology 74:1767-1777

Clay K, Holah J (1999) Fungal endophyte symbiosis and plant diversity in successional fields. Science 285:1742-1744

Clay K, Schardl C (2002) Evolutionary origins and ecological consequences of endophyte symbiosis with grasses. Am Nat 160:S99-S127

Clay K, Holah J, Rudgers JA (2005) Herbivores cause a rapid increase in hereditary symbiosis and alter plant community composition. PNAS 102:12465-12470 
Cheplick GP, Clay K, Marks S (1989) Interactions between infection by endophytic fungi and nutrient limitation in the grasses Lolium perenne and Festuca arundinacea. New Phytol 111:8997

Grime JP (1979) Plant Strategies and Vegetation Processes. John Wiley \& Sons, Chichester Gundel PE, Zabalgogeazcoa I, Vázquez-de-Aldana BR (2011) Interaction between plant genotype and the symbiosis with Epichloë fungal endophytes in seeds of red fescue (Festuca rubra). Crop Pasture Sci 62:1010-1016

Harberd DJ (1961) Observations on population structure and longevity of Festuca rubra L. New Phytol 60:184-206

Hesse U, Hahn H, Andreeva K, Forster K, Warnstorff K, Schoberlein W, Diepenbrock W (2004) Investigations on the influence of Neotyphodium endophytes on plant growth and seed yield of Lolium perenne genotypes. Crop Sci 44:1689-1695

Hill NS, Belesky DP, Stringer WC (1991) Competitiveness of tall fescue as influenced by Acremomium coenophialum. Crop Sci 31:185-190

Hoveland CS, Durham RG, Bouton JH (1997) Tall fescue response to clipping and competition with no-till seeded alfalfa as affected by fungal endophyte. Agron J 89:119-125

Inderjit, Wardle DA, Karban R, Callaway RM (2011) The ecosystem and evolutionary contexts of allelopathy. Trends Ecol Evol 26:655-662

Leuchtmann A, Schmidt D, Bush LP (2000) Different levels of protective alkaloids in grasses with stroma-forming and seed-transmitted Epichloe/Neotyphodium endophytes. J Chem Ecol 26:1025-1036

McGilchrist CA, Trenbath BR (1971) A revised analysis of plant competition experiments. Biometrics 27:659-677

Malinowski DP, Leuchtmann A, Schmidt D, Nosberger J (1997) Symbiosis with Neotyphodium uncinatum endophyte may increase the competitive ability of meadow fescue. Agron J 89:833839

Malinowski DP, Alloush GA, Belesky DP (1998a) Evidence for chemical changes on the root surface of tall fescue in response to infection with the fungal endophyte Neotyphodium coenophialum. Plant Soil 205:1-12

Malinowski DP, Belesky DP, Hill NS, Baligar VC, Fedders JM (1998b) Influence of phosphorus on the growth and ergot alkaloid content of Neotyphodium coenophyalum-infected tall fescue (Festuca arundinacea Schreb.). Plant Soil 198:53-61

Malinowski DP, Belesky DP, Fedders JM (1999) Endophyte infection may affect the competitive ability of tall fescue grown with red clover. J Agron Crop Sci 183:91-101 
Malinowski DP, Belesky DP (2000) Adaptations of endophyte-infected cool-season grasses to environmental stresses: Mechanisms of drought and mineral stress tolerance. Crop Sci 40:923940

Marks S, Clay K, Cheplick GP (1991) Effects of fungal endophytes on interspecific and intraspecific competition in the grasses Festuca arundinacea and Lolium perenne. J Appl Ecol 28:194-204

Marschner H (1995) Mineral Nutrition of Higher Plants. Academic Press, London Ponce MA, Bompadre MJ, Scervino JM, Ocampo JA, Chaneton EJ, Godeas AM (2009) Flavonoids, benzoic acids and cinnamic acids isolated from shoots and roots of Italian rye grass (Lolium multiflorum Lam.) with and without endophyte association and arbuscular mycorrhizal fungus. Biochem Syst Ecol 37:245-253

Renne IJ, Rios BG, Fehmi JS, Tracy BF (2004) Low allelopathic potential of an invasive forage grass on native grassland plants: a cause for encouragement? Basic Appl Ecol 5:261-269

Richmond DS, Grewal PS, Cardina J (2003) Competition between Lolium perenne and Digitaria sanguinalis: Ecological consequences for harbouring an endosymbiotic fungus. J Veg Sci $14: 835-840$

Rodriguez RJ, White Jr JF, Arnold AE, Redman RS (2009) Fungal endophytes: diversity and functional roles. New Phytol 182:314-330

Saikkonen K, Wäli P, Helander M, Faeth SH (2004) Evolution of endophyte-plant symbioses. Trends Plant Sci 9:275-280

Saint Yves A (1930) Aperçu sur la distribution géographique des Festuca (Subgen. Eu-Festuca). Candollea 4:146-165

San Emeterio LS, Arroyo A, Canals RM (2004) Allelopathic potential of Lolium rigidum Gaud. on the early growth of three associated pasture species. Grass Forage Sci 59:107-112

Sanchez Marquez S, Bills GF, Herrero N, Zabalgogeazcoa I (2012) Non-systemic fungal endophytes of grasses. Fungal Ecol 5:289-297

Schardl CL, Phillips TD (1997) Protective grass endophytes: Where are they from and where are they going? Plant Dis 81:430-438

Shelby RA, Dalrymple LW (1993) Long-term changes of endophyte infection in tall fescue stands. Grass Forage Sci 48:356-361

Siegel MR, Bush LP (1996) Defensive chemicals in grass-fungal endophyte associations. Recent Adv Phytochem 30:81-120

Torres MS, White Jr JF, Zhang X, Hinton DM, Bacon CW (2012) Endophyte-mediated adjustments in host morphology and physiology and effects on host fitness traits in grasses. Fungal Ecol, in press doi: 10.1016/j.funeco.2011.05.006 
Vázquez-de-Aldana BR, García-Criado B, Zabalgogeazcoa I, García-Ciudad A (1999) Influence of fungal endophyte infection on nutrient element content of tall fescue. J Plant Nutr 22:163-176 Vázquez-de-Aldana BR, García-Ciudad A, García-Criado B (2008) Interannual variations of above-ground biomass and nutritional quality of Mediterranean grasslands in Western Spain over a 20-year period. Aust J Agric Res 59:769-779

Vázquez-de-Aldana BR, Zabalgogeazcoa I, Rubio de Casas R, García-Ciudad A, García-Criado B (2010) Relationships between the genetic distance of Epichloë festucae isolates and the ergovaline and peramine contents of their Festuca rubra hosts. Ann Appl Biol 156:51-61 Vázquez-de-Aldana BR, Romo M, García-Ciudad A, Petisco C, García-Criado B (2011) Infection with the fungal endophyte Epichloë festucae may alter the allelopathic potential of red fescue. Ann Appl Biol 159:281-290

Wäli PR, Helander M, Saloniemi I, Ahlholm J, Saikkonen K (2009) Variable effects of endophytic fungus on seedling establishment of fine fescues. Oecologia 159:49-57

Wilkinson HH, Siegel MR, Blankenship JD, Mallory AC, Bush LP, Schardl CL (2000) Contribution of fungal loline alkaloids to protection from aphids in a grass-endophyte mutualism. Mol Plant Microbe In 13:1027-1033

Zabalgogeazcoa I, Vázquez-de-Aldana BR, García-Criado B, García-Ciudad A (1999) The infection of Festuca rubra by the fungal endophyte Epichloë festucae in Mediterranean permanent grasslands. Grass Forage Sci 54:91-95

Zabalgogeazcoa I, García-Ciudad A, Vázquez-de-Aldana BR, García-Criado B (2006) Effects of the infection by the fungal endophyte Epichloe festucae in the growth and nutrient content of Festuca rubra. Eur J Agron 24:374-384

Zaurov DE, Bonos S, Murphy JA, Richardson M, Belanger FC (2001) Endophyte infection can contribute to aluminum tolerance in fine fescues. Crop Sci 41:1981-1984 
Table 1 Summary of ANOVA results of the effects of plant line (PEN, RAB), endophyte status $(\mathrm{E}-, \mathrm{E}+)$ and competition with red clover (monoculture, mixture) on growth parameters of Festuca rubra

\begin{tabular}{|c|c|c|c|c|c|c|c|c|c|}
\hline \multirow[t]{2}{*}{ Effect } & \multicolumn{3}{|c|}{ Shoot dry matter } & \multicolumn{2}{|c|}{ Root dry matter } & \multicolumn{2}{|c|}{ Root:Shoot } & \multicolumn{2}{|c|}{ Tiller number } \\
\hline & $\mathrm{df}$ & $F$ & $P$ & $F$ & $P$ & $F$ & $P$ & $F$ & $P$ \\
\hline Line (L) & 1 & 83.76 & $<0.001$ & 22.56 & $<0.000$ & 0.935 & 0.341 & 54.88 & $<0.000$ \\
\hline Endophyte (E) & 1 & 10.96 & 0.002 & 6.424 & 0.017 & 23.97 & 0.000 & 15.21 & 0.001 \\
\hline Competition (C) & 1 & 0.023 & 0.879 & 0.010 & 0.922 & 0.003 & 0.956 & 2.391 & 0.132 \\
\hline$L \times E$ & 1 & 21.38 & $<0.000$ & 16.31 & 0.000 & 174.5 & 0.000 & 10.49 & 0.003 \\
\hline$L \times C$ & 1 & 0.039 & 0.845 & 0.799 & 0.379 & 2.074 & 0.160 & 0.003 & 0.957 \\
\hline$E \times C$ & 1 & 0.920 & 0.345 & 0.387 & 0.539 & 0.000 & 0.993 & 0.000 & 0.994 \\
\hline$L \times E \times C$ & 1 & 5.367 & 0.028 & 1.976 & 0.170 & 0.002 & 0.968 & 0.250 & 0.621 \\
\hline
\end{tabular}

Significant $P$-values are in bold $(P>0.05)$ 
Table 2 Summary of ANOVA of the effect of plant line (PEN, RAB) and endophyte status (E+, E-) of Festuca rubra plants on the growth of Trifolium pratense, Trifolium repens, Trifolium subterraneum, Lotus corniculatus and Plantago lanceolata.

\begin{tabular}{|c|c|c|c|c|c|c|c|c|c|c|}
\hline \multirow[t]{2}{*}{ Target species } & \multirow[t]{2}{*}{ Factor } & \multirow[b]{2}{*}{ df } & \multicolumn{2}{|c|}{$\begin{array}{c}\text { Shoot dry } \\
\text { matter }\end{array}$} & \multicolumn{2}{|c|}{ Root dry matter } & \multicolumn{2}{|c|}{ Shoot length } & \multicolumn{2}{|c|}{ Root length } \\
\hline & & & $F$ & $P$ & $F$ & $P$ & $F$ & $P$ & $F$ & $P$ \\
\hline \multirow[t]{3}{*}{ T. pratense } & Line (L) & 1 & 0.351 & 0.562 & 1.04 & 0.323 & 0.231 & 0.638 & 0.457 & 0.509 \\
\hline & Endophyte (E) & 1 & 4.47 & 0.050 & 18.7 & 0.001 & 0.727 & 0.406 & 4.48 & 0.050 \\
\hline & $\mathrm{L}^{*} \mathrm{E}$ & 1 & 0.066 & 0.800 & 0.092 & 0.765 & 0.059 & 0.812 & 1.63 & 0.219 \\
\hline \multirow[t]{3}{*}{ T. repens } & Line (L) & 1 & 6.91 & 0.018 & 1.23 & 0.248 & 13.2 & 0.002 & 3.28 & 0.089 \\
\hline & Endophyte (E) & 1 & 4.18 & 0.050 & 4.59 & 0.048 & 8.33 & 0.011 & 14.3 & 0.002 \\
\hline & $L^{*} I$ & 1 & 0.157 & 0.697 & 0.070 & 0.749 & 6.23 & 0.020 & 0.359 & 0.557 \\
\hline \multirow[t]{3}{*}{ T.subterraneum } & Line (L) & 1 & 1.22 & 0.284 & 0.449 & 0.513 & 11.4 & 0.004 & 5.24 & 0.037 \\
\hline & Endophyte (E) & 1 & 0.000 & 0.983 & 10.8 & 0.005 & 0.559 & 0.465 & 8.26 & 0.012 \\
\hline & $L^{*} E$ & 1 & 0.262 & 0.616 & 0.003 & 0.956 & 0.331 & 0.573 & 0.005 & 0.943 \\
\hline \multirow[t]{3}{*}{ L. corniculatus } & Line (L) & 1 & 2.30 & 0.150 & 0.025 & 0.875 & 0.324 & 0.577 & 4.39 & 0.052 \\
\hline & Endophyte (E) & 1 & 4.09 & 0.061 & 9.92 & 0.006 & 5.17 & 0.037 & 0.073 & 0.790 \\
\hline & $\mathrm{L}^{*} \mathrm{E}$ & 1 & 0.064 & 0.804 & 2.49 & 0.134 & 1.58 & 0.226 & 1.31 & 0.268 \\
\hline \multirow[t]{3}{*}{ P. lanceolata } & Line (L) & 1 & 1.15 & 0.299 & 0.999 & 0.333 & 0.324 & 0.577 & 2.05 & 0.172 \\
\hline & Endophyte (E) & 1 & 8.33 & 0.011 & 22.8 & 0.000 & 0.001 & 0.974 & 7.70 & 0.014 \\
\hline & $L^{*} E$ & 1 & 0.018 & 0.895 & 1.49 & 0.241 & 0.467 & 0.588 & 0.556 & 0.467 \\
\hline
\end{tabular}

Significant $P$-values are in bold $(\mathrm{P}>0.05)$ 
Fig. 1 Effect of fungal endophyte ( $E+=$ infected, $E-=$ non-infected) on shoot and root biomass, number of tillers and root:shoot ratio in plants of Festuca rubra lines PEN and $\mathrm{RAB}$, growing in monoculture and in mixture with Trifolium pratense (mono, Tprat). Bars indicate means $\pm S E(n=5)$

Fig. 2 Effects of fungal endophyte (E+ = infected; $E-=$ non-infected) on nitrogen and phosphorus concentration in shoots and roots of Festuca rubra lines (PEN and RAB), growing in monoculture and in mixture with Trifolium pratense (mono, Tprat). Bars indicate means $\pm S E(n=5)$

Fig. 3 Shoot and root biomass, and phosphorus concentration of Trifolium pratense growing in monoculture (black bars) and in mixture with infected ( $E+$, gray bars) and with non-infected (E-, white bars) Festuca rubra lines PEN and RAB. Bars indicate means $\pm S E(n=5)$

Fig. 4 Shoot and root biomass and length in Trifolium pratense, Trifolium repens, Trifolium subterraneum, Lotus corniculatus and Plantago lanceolata growing in mixture with infected $(\mathrm{E}+)$ and non-infected (E-) plants of Festuca rubra lines PEN and RAB. Values are relative to monoculture. Bars indicate means $\pm S E(n=5)$ 

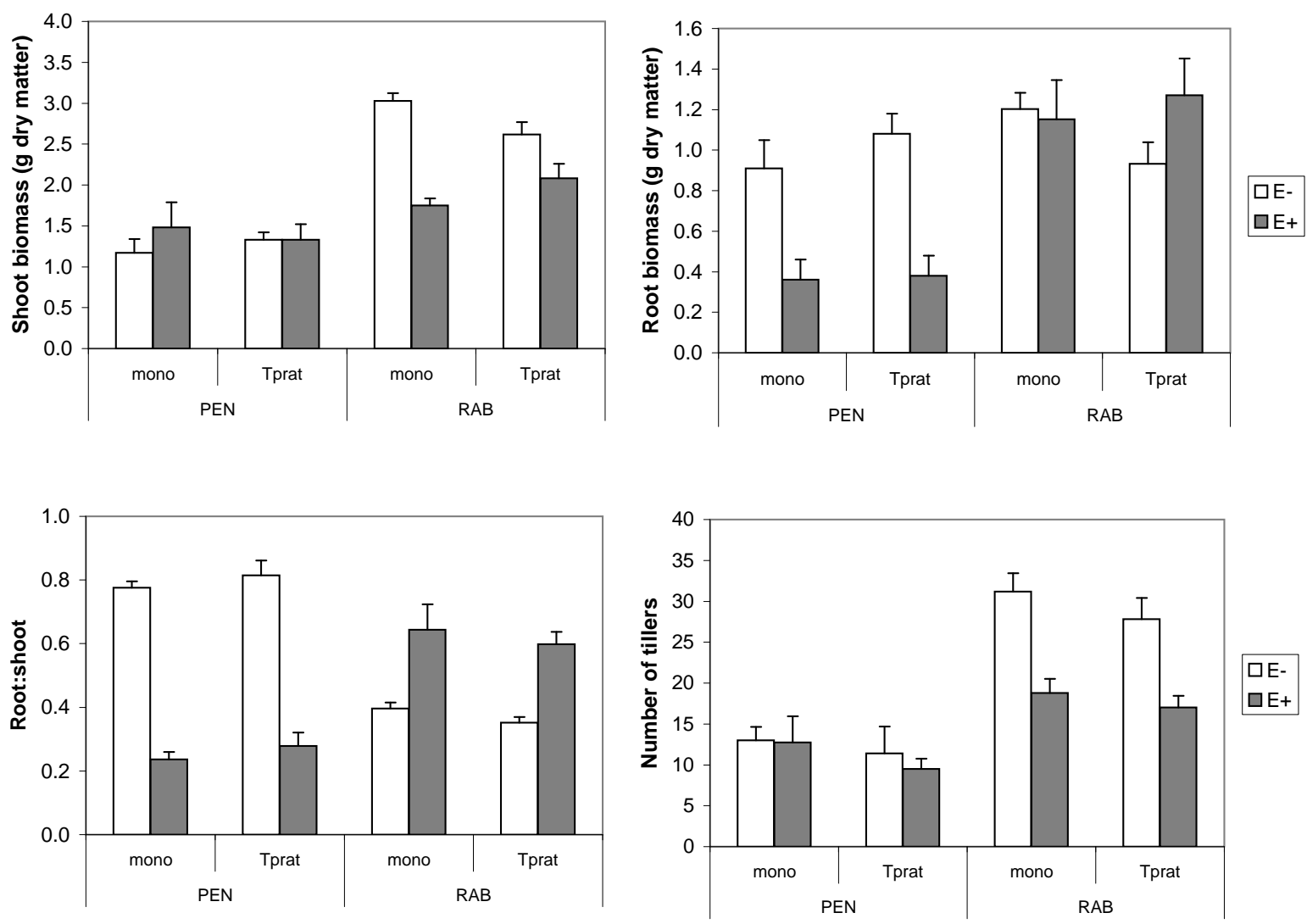

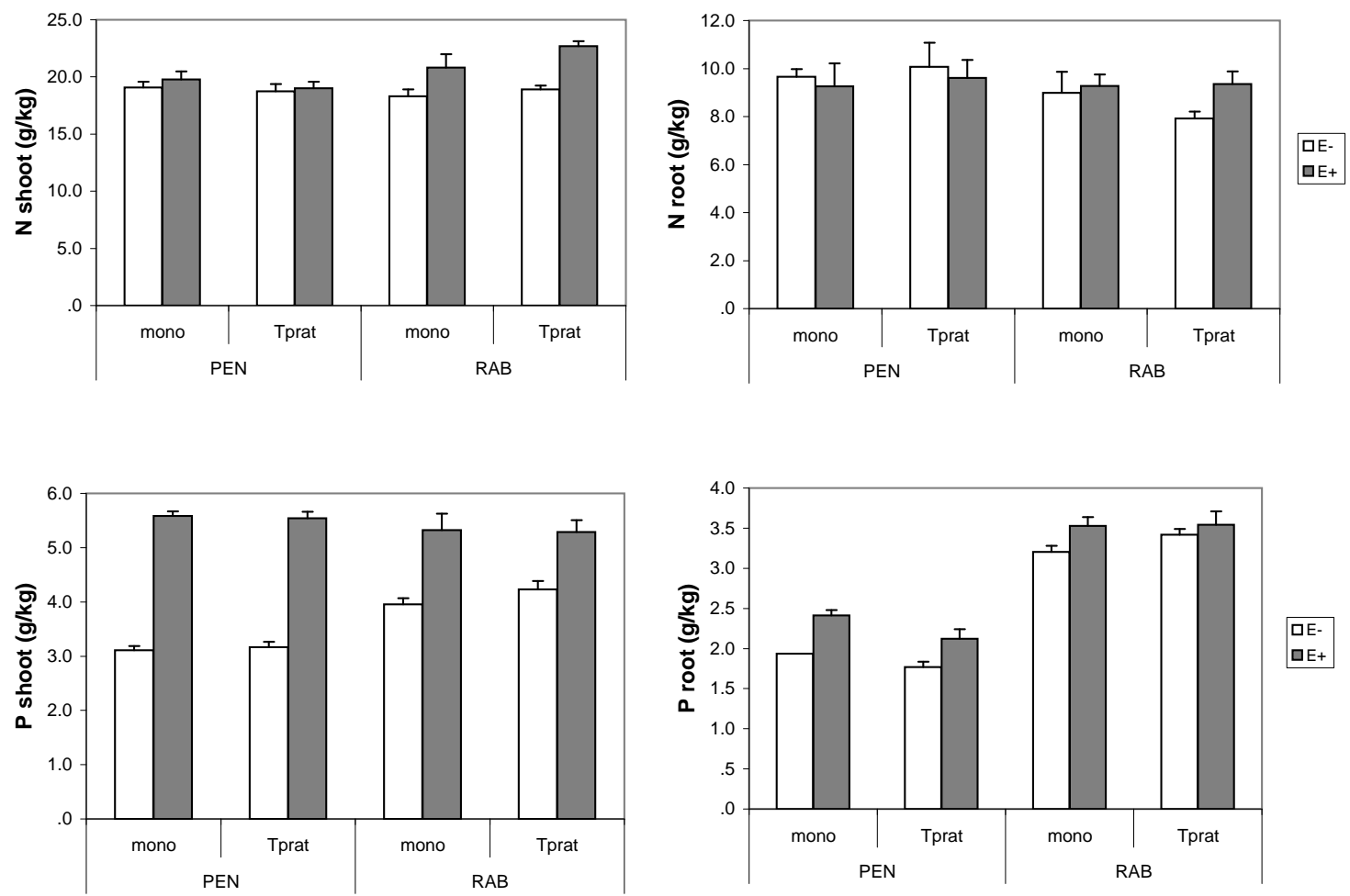

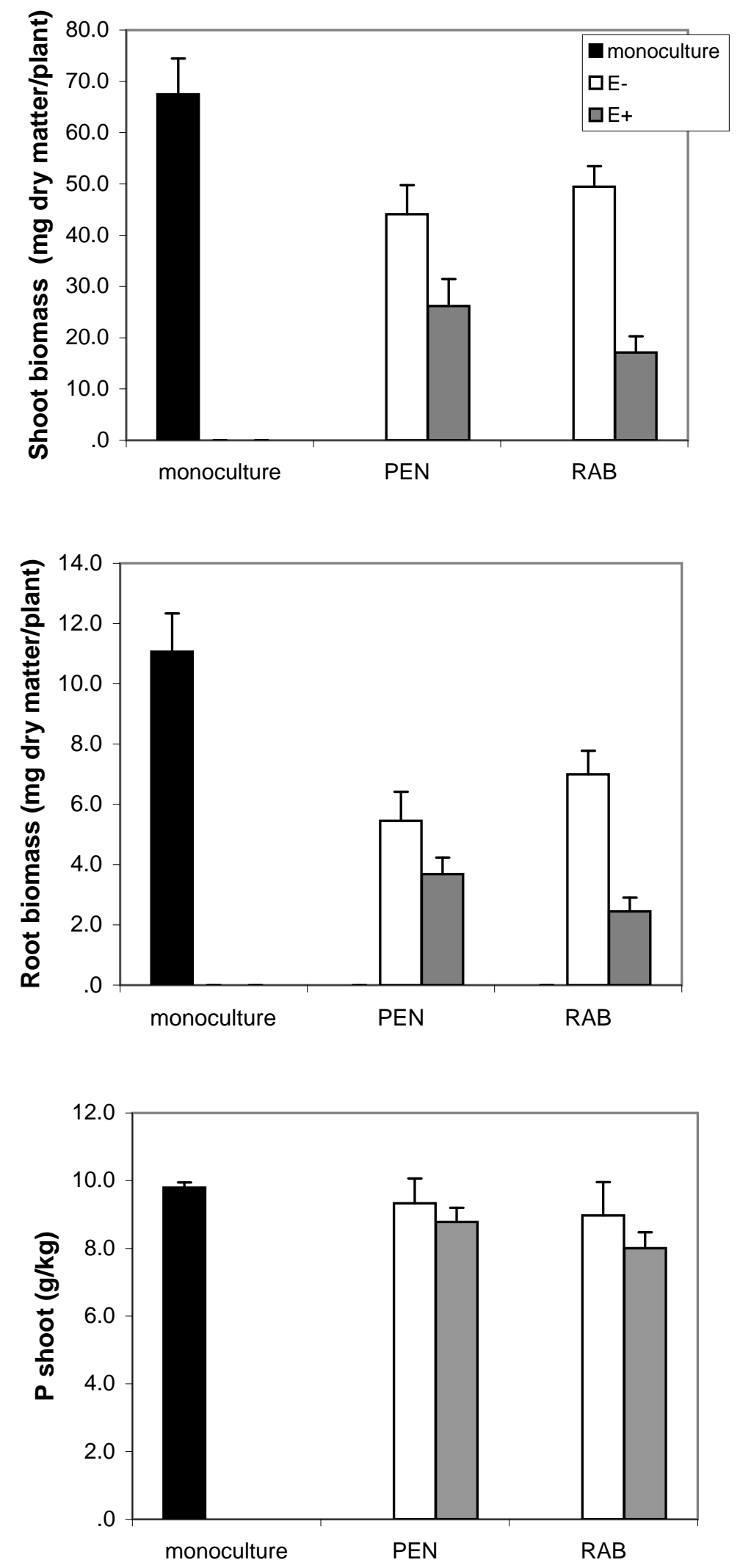

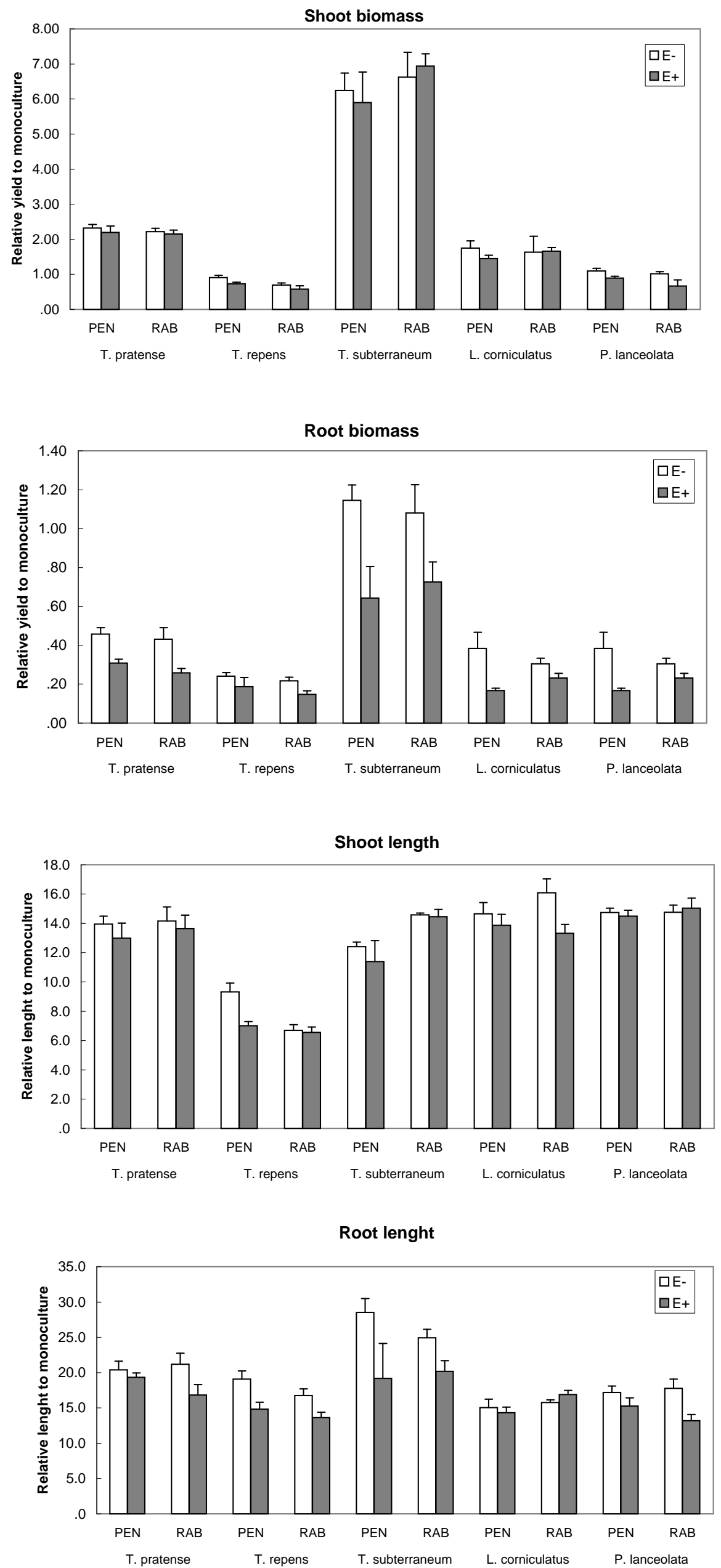